\title{
To Hear Ergo To See, or On the Acoustic Specificity of the Ceremonial Performances of Amur Peoples
}

\author{
Iana S. Kryzhanovskaia* \\ Khabarovsk State Institute of Culture \\ 112 Krasnorechenskaia Str., Khabarovsk, 680045, Russia
}

Received 20.01.2016, received in revised form 30.03.2016, accepted 28.05.2016

The present article presents the analyses acoustic components of traditional culture of the peoples living in the South of the Far East Region. Recognizing the significance of "ceremonial performance text" as a compound system of choreog-raphy, stage design and acoustic component, the author emphasizes the performance basis of the ritual syncretism. The author demonstrates that the roots of the Amur acoustic world perception should be sought for in the system of visual, emotional and sensual, kinetic components associated with the imitation nature of the Amur ceremonial performances. The research develops the idea that due to syncretic consciousness, the acoustic layer of Amur rituals did not just provide the audience with some audial impressions, but also translated them into visual, thereby proving the audiovisual unity of a tribal man's consciousness.

Keywords: ethnos, ceremonial performance, Amur-Sakhalin Region, syncretism, sound imitation.

DOI: 10.17516/1997-1370-2016-9-6-1295-1306.

Research area: culture studies.

Traditionalculture of suchindigenous peoples of the South of the Far East, as the Nanai, Nivkh, Orochs, Udege etc. cannot be imagined separate from studies of their ceremonial performance phenomenon. The heritage of the Amur-Salkhalin peoples includes such performance forms as rituals, celebrations, shamanistic rituals, as well as some fairy-tale folklore elements, such as actions done for the sacral Spectator, God, spirit, or supreme SOMEONE created by the group itself is thought to be. The Spectator in such case was not so much a real and visible observer, as a factor of the performer's consciousness, or, following the formulation offered by J. Lacan, as "... sight created in that of another by my own imagination" (Lacan, 2004: 94). No ritual activity was expected from such Spectator, as the actor of the ritual was a man, the one performing the magic action. The performance (the ceremonial performance) as such was the optimal spot for physical and psychological contact between the performance actors and the Audience.

The conceptual basis for culture studies of such ceremonial performances may be the system approach, briefly and clearly defined by Y.M. Lotman as follows: "The main feature of structural study is that it assumes the studies not of separate elements isolated or mechanically conjoined, but of the interrelation between the elements and their relation to the structural whole. It is inseparable

(C) Siberian Federal University. All rights reserved

* Corresponding author E-mail address: krijanowsckaia.yana2012@yandex.ru 
from the studies of functional nature of the system or its parts" (Lotman, 1994: 18). Considering traditional performance within the systematic approach, we also believe it necessary to use the law of irregular development of different kinds of artistic activity at the different stages of culture history, discovered by G. Hegel and proved by M.S. Kagan, as methodological base.

Admitting significance of the "ceremonial performance text" as a compound system of choreography (gesture and mimics), stage design (items and space) and acoustics, let us remark that from our point of view this syncretism developed on the basis of performance. Within the framework of systematic approach, it means not only unconditional domination of visual means of communication, but also the influence the performance component makes on all other means of expression.

An integral part of a ceremonial performance text is its acoustic component. As the subject matter is sound in the general sense, including human voice (from whisper to signing and screaming) and sounds of music, and noises produced by people (purposefully or unintentionally) which cannot be defined as music, but a specific form of intonement behaviour. Existing research of paleosonorous field operates the terms of "intonement-acoustic" or "sound culture", which means "formation of sound environment in the process of social life by ethnos representatives" (Sheykin, 2002: 32).

In the ceremonial performance structure, sound was not just a way of complementing the visual sequence, including the actional and objective-material aspects, but also had its own meaning and ground. No matter how paradoxically it may sound, but it had a visual side of its own.

Uunderdevelopment of the music spectacularity and theatre adaptation problems hits the eye: most of the times, the subject matter is the elementary forms of sound mimesis. However, the problem looks much more complicated. In particular, archaic spectacular arts (ceremonial folklore, fairy-tales) studies require considering the syncretic (not purely artistic) character of such actions. Our hypothesis states that within the framework of ceremonial syncretism formed on the performance basis, the acoustic sequence was formed through the transformation ("translation") of visual impressions into intonement and was influenced by either actional or objective-visual medium. In the first case we have a developed rhythmic-intonement language (figurativeness of movements and gestures caused by the peculiarities of rhythm and melodic pattern), and in the second the emphasis is made on the timbreintonement component (acoustic figurativeness, kinetic images of the landscape etc.).

Within the mythological thinking context, perceiving and representing the world in the diversity and integrity of all its material and spiritual aspects, where sound ("voice") is an essential attribute of the living, the acoustic filling of the environment caused semiotization of natural sounds. They were given meanings and perceived as voices belonging to certain subjects and communicative partners, let those be real or sacral, personified spirits or deities, rather than random sounds of "non-living" origin. It is no coincidence that in the Nivkh language there is no differentiation between voice, sound, and noise, referred to as $a u(y u)$, and in the Nan language the word dzilgan means both human voice, sounds of music and birds' singing (Slovar', 2000: 95). In traditional Amur culture all sounds, undivided into human sounds and sounds of nature, are not relevant on their own, as an acoustic phenomenon; they matter as "voices", as acoustic incarnations of certain recognizable visual images, as transformations of visual impressions into intonement complexes. That is the reality of sound that made the "presence" of mythological 
events and their participant characters possible, provided the "visualness" of such events and characters in the ceremonial performance.

Visualization of sounds with certain visible and recognizable images behind them manifested itself through vocal and instrumental, accurate and stylized imitation of physical and biological nature sounds, as well as non-verbal forms of acoustic imitation: natural phenomena, vocal and mechanic signals produced by animals and birds, sounding human kinetics etc. This given type of sound performance refers to the most ancient type of communication between human and environment.

1. "Naturalistic" (accurate) imitations of voices of animals and birds, a sort of "sound performances of the subjective world" (Iu. Kremlev), are close imitations of original sounds (shriek, howl, whistle, twitter etc.). They include a mimetic sound performance complex, which is one of the most ancient sound phenomena on the planet: "biological" music. Due to extreme sensitivity of the Amur peoples to the sound phenomena of the environment, the sound imitation conveying acoustic characteristics of phenomena and subjects may vary both in character and in the method of performance.

All peoples of the South of the Far East Region had their vocal and instrumental (pipes, bird calls, whistles, mouth organ etc.) ways of imitating the voices of birds (crow, cuckoo, seagull, loon, goose, hazel grouse, owl, black woodpecker etc.) and forest animals (bear, dog, fox, hare, squirrel, wolverine, chipmunk etc.). Such calling was of practical character, used in hunting practice. The Nivkh, engaged with deep sea fishing, had an extensive system of sea animal voices' imitation.

As noticed by E.A. Kreynovich, the Nivkh hunters knew some seal calling sounds: a young eared seal was called with the sound urururu, and a big one with the nasal $u g h$; small seals of a certain kind are better to be called with the sound gahp, while for a different kind $p u, p u$ sound is used. To call $k^{\prime}$ ad seal, a low roaring sound g'aghp' was produced by means of rough fraction of air against laryngeal chords, not with the mouth cavity (Kreynovich, 2001: 172). However, the sound marking of animals and birds is not limited to hunting purposes. Onomatopoeia was widely used in ritual practice, creating the so-called "sound landscape", serving as base for some traditional music genres. According to Iu.I. Sheykin, there is a specific type of vocal sound producing in the music folklore of the Far East peoples: alamasini (Udege), dilgan (Negid.), dzildan (Oroch), with literally means "to produce sounds or sing, imitating the voice of an animal or a bird" (Slovar', 2000: 93).

Accurate sound imitations were widely used in shamanistic rituals: to call shaman's helper spirits with a corresponding (zoomorphic or ornitomorphic) appearance, or to announce their "arrival" to the shaman's call. For example, during the farewell ceremony of buni, intended to send off a soul into the Afterworld, the shaman would do the ritual calling the Underworld birds that live, according to the Nanai mythology, on the nine branches of the world tree. At the same time, besides the mythic birds, some recognizable real birds are also imitated: those are cuckoo (in the Amur peoples' mythology, a guide of the departed souls in the Underworld) and turtle dove. The shaman would imitate these birds vocally or using a mouth drum, imitating both the voice and other sounds, such as wing clapping. Thus, among the Nivkh people it was popular to play a grass mouth drum called k'ol ch'nyr, which makes sounds similar to the squawk of a bird as it takes off from the ground. The Lower Amur peoples imaged a soul departing to buni in the shape of a bird. That is why, saying farewell to its family, "a soul speaks bird language" - kekuyni (Nanai from $k e k u$, "to cuckoo"), and the shaman 
translates its words as he does his ritual (Smoljak, 1991: 158).

Inside the ritual such intonement complexes worked as an acoustic mask to hide one's own face and to reveal that of another. Regular people could feel the presence of spirits exclusively from the sounds they made: the shaman's "helpers", invisible for everyone except for the shaman himself, would reveal themselves through sound imitation. Depending on what the shaman transformed into, he would use specific sound producing techniques, such as various kinds of laryngeal and throat tremolo, trills, as well as groans, howling, barking etc. Trying to present the sounds of the surrounding world as naturally as possible, the shamans would often use their drums heated on the fire as a resonator and a stick, while imitating the voices of animals and birds. Thus, according to A.S. Kolosovsky who was present at the ritual performed by the Nivkh female shaman Sevgun in 1984, the shaman moved sideways, holding the drum in her left hand, and knocked on the door post with the stick to imitate the voice of a woodpecker (Kolosovskij, 2008: 258).

There were other instruments that could be used in the ceremonial actions to reproduce the sounds of nature: those are fuali (Udege), p'uvr, a vortex aerophone used to imitate the sound of wind. It was a prolate plate or a wooden button rapidly rotated around its axis to make a buzzing sound. The Nivkh believed that the sound could be used to call the wind. It is also proven by the diary records of E.V. Kreynovich: "The old man would always get angry when children played with that toy; he told them to stop, or there would be wind. Every time he found a toy like that, he would always throw it into the fire" (Mamcheva, 2008: 134). Rotation of the vortex aerophone winged the air, making a sharp shrieking sound symbolizing the wind.

Ritual onomatopoeia of the Nivkh is widely represented in the bear holiday procedure. E.A.
Kreynovich described a ritual made after flaying of a bear carcass, during which some old men, standing on both sides of the carcass, throw the bear skin over it and beat the bear, imitating the bear roar throughout the ritual (Kreynovich, 2001: 235). The bear voice imitation sounded in the moment when the bear skin together with its head was brought into the house down the chimney. As the bear head appeared, the owner of the house would ask it questions in a singsong voice, and "the bear would roar in return. The Nivkh women would knock against a log strongly and rhythmically, and the bear would roar in a friendly way, as though it knew and it understood who had made its meals, who had fed it with pork fat, who had given it water. It would roar, roar and roar" (Kreynovich, 2001: 242).

In all similar cases the animals and birds' sounds imitation would either accompany a visible image (of a bear, a bird etc.) or replace it, to make the audience see it with "internal sight" (during the shaman ritual), producing bright visual images through the acoustic phenomena. Within the paradigm of visual and audial images the visible space of the ceremonial performance was perceived by both sight and hearing, and there was a sign of approximate (non-identical) equation between the heard and the seen.

2. "Symbolic" onomatopoeia does not imitate the original sound as accurately, but it conveys the general sound impression, melodizing the acoustic signals of nature. Here we speak not of mechanic transposition of nature phenomena or copying, but of intentional sound creation with a distinctive emotional connotation. Within a ceremonial performance such "refined", melodically intonated imitation of natural sounds, transformed into a cultural symbol, as well as reflective exclamations of people (laughter, cry etc.), still remains in instrumental folk tunes or in specific sound-imitating chants, a sort of vocal folk tunes. 
An important element of funeral and obituary rituals of the indigenous peoples of the Amur and Sakhalin was playing unichord or mouth drum to imitate the sound of crying. In the past, in the South of the region there was a single-string bow instrument with a timbre similar to that of a viola. The resonator of the instrument was a hollow cylinder (wooden, tin, birch bark). The Nivkh called such bow instrument tyngryn, the Ulch called it tengkere or sirpakta, the Oroch - dudumanku, the Nanai-duuchieke, and the Udege-dziulianka. There are multiple legends of the origin of the instrument telling the stories of how the unichord was used to substitute the human voice to express the grief of losing nearest and dearest. The Amur-Sakhalin Region peoples had a tradition, according to which the last surviving family member had to make a bow monochord to mourn for the dead.

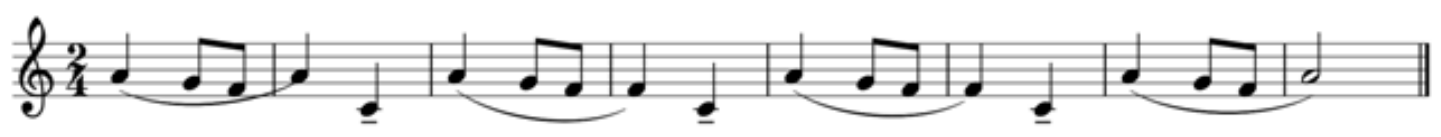

In the instrumental mourning tune we notice falling tones, plenty of step motives ("moaning" motives), i.e. all the techniques used to convey the emotional and psychological state of mourn in musical tradition. However, despite the distinctively imitating character creating a specific visual image, the subject matter is symbolic sound imitation with a bright melodic aspect.

Another phonic instrument used by the peoples of the South of the Far East Region in their funeral and obituary rituals was an arched metallic mouth drum called muene, menge (Nanai), kunkai (Udege, Ulch), mukhele (Ulch), symbolizing masculine mourning for tribe mates. It is interesting that the voice is always reproduced (the mouth drum is played) by a woman (Slovar', 2000: 101).

There is an Ulch legend telling of the origin of the instrument. Once upon a time, in a village there lived three brothers and a sister. A big larch grew on the top of a cliff. Once a bird came and settled on the top of the tree. The eldest brother wanted to take a look at the bird, but as soon as he opened the door, he dropped down dead. The second brother also went to see the bird and died. Then the third, the youngest brother wanted to see the bird, and he also died right at the doorstep. All three brothers were dead. Only their young sister was alive, who mourned for her brothers day and night. Once she went out, found an old lath and made a musical instrument called holdekto kunkai. She played and cried day and night, until the instrument broke in halves. After that she decided to make and iron instrument called mukhene. So, playing it and crying, she walked away down the Amur. People lost her; someone heard she got married and went no one knows where.

The popularity of kanga mouth drum among the Nivkh was noticed long ago by L.Ia. Sternberg who described the mourning songs cheriond played on this instrument before cremation. Such instrumental tunes were not accompanied by any singing; they worked as an intonement imitation of crying.

Imitation of crying imitation on a unichord and a mouth drum during ceremonial actions reproduced a certain type of behaviour accompanied with human emotions. But any sort of behaviour always has its bearer; so, imitating crying, the sounds of the instrument, at the same time, represent a subject, or a human, making him visible. It is notable that the real performer 
playing the instrument and the emotion bearing subject, represented through the sounds of music, are different characters, which is emphasized even with a gender mismatch. According to Iu. Sheykin, a unichord violin symbolized (substituted) the voice of a beloved woman but was played by a man. On the opposite, the sounds of a mouth drum represented a man's cry performed by a woman.
Melodized imitation was used by the Nivkh in ceremonial actions involving interaction with birds. For example, the sounds of kalni trumpets were used to imitate the voices of swans or geese. During birds' migration, a woman would come out on the river bank, raise the instrument made of umbelliferous plant scape like a megaphone, point it into the sky and sing melodies with guttural trills through it.

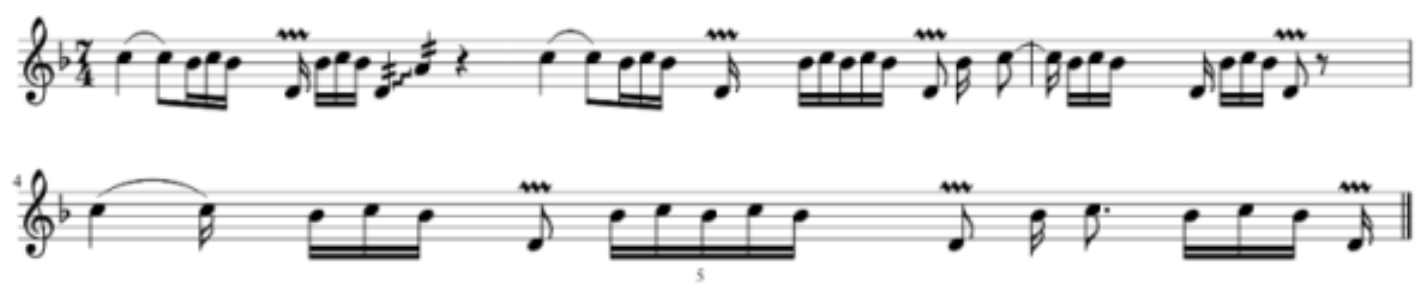

In this example provided by N.A. Mamcheva (Mamcheva, 1995: 184), besides the sliding sounds, trills and other micromoves intended to (combined with the fluctuating tempo, improvisation and freedom of variation development) imitate the sounds of birds' voices, the attention is drawn by the minor sixth intonation forming a sort of sound pattern of this vocal tune, making it distinctively melodic and even songful. Naturalistic bird voice imitation is richer in perfect inrterval leaps, i.e. the perfect consonance, the acoustic properties of which exist in nature itself, such as fourth, fifth and eighth; in symbolic imitations the sixth, being an imperfect consonance, comes to the fore.

Symbolic sound imitations were used in children's and adults' games coming from ancient rituals and still bearing some syncretic character. N.A. Mamcheva presents some intoned calls sung by children to address a loon, one of the key birds in the Nivkh mythology. "When sometimes a loon flew up the river, away from the sea, the children called: 'Arnarna, arnarna! Fly back. Don't fly there, fly back, come back. Your sister will get you soon. Your sister carries a knife and a board. She will cut you on the board with her knife! Your sister is getting you! Back, fly back!'
And as though the bird understood them, it would go nagvoty-nagvoty-nagvoty, ay-ay-ay and fly back" (Mamcheva, 2006: 143).

For imitation of the loon voice, semi-musical intonation with clear perfect eighths and fifths, the basic perfect consonance with a strong rhythmic pattern is used. Deviation from the original was explained by the mixed, vocal and verbal type of intonation and the presence of game elements (melodized call for the loon, a dialogue with the bird). For this reason such intonement is classified as symbolic sound imitation, a "vocal tune".

Imitation of waterfowl birds (loons, as well as ducks, geese, swans, cranes) is wide-spread in the culture of the peoples of the South of the Far East. They occupy the central position in their mythology as creators of the land; pictures of such birds are often found in petroglyphs, in decorative elements, and are often used in various games. Iu.A. Sem describes Akoanlandi imitation game played in summer by the Nanai (Sem, 1988: 125). It was previously mentioned by A.N. Lipsky, calling it Akualanzi, and by I.A. Lopatin who called it Akalandzhini (Lopatin, 1921: .39). In the game girls imitated birds: ducks, swans, or herons. They swatted on their haunches, 
thrusting their elbows out, hands on hips. Then, jumping, they moved towards each other. The purpose of the game was to knock the opponent down by pushing her with bent arms, imitating the movements of birds' wings and imitating the voice of the bird. As noticed by B. Podmaskin, in similar games of the Udege freestyle vocal imitation of birds' voice was compulsory (Podmaskin, 1987: 30). Stylized sound imitations were also used in boar or bear games. Besides vocal imitations, the games involved instrumental ones; for example, different reedpipes, whistles etc. were used to imitate the birds' voices (Udege kiuosingku, or kigosingku, an end-blown whistle flute made of osier-bed).

A more frequent variant is connected with tone-painting techniques in fairy-tales, where animals' and birds' voice imitation is especially common. Onomatopoetic motives in narrative folklore texts mark the direct speech of zoomorphic character as a repetend. Thus, in Nanai fairytale Gindeken ("The Titmouse") a motive imitating this bird's song is repeated:

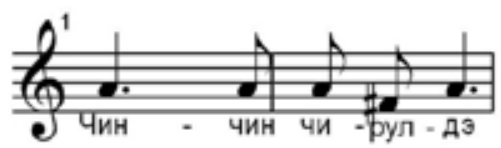

Illustrative traits can be also found in the birds involving episods of the Nivkh fairytale “The Two Brothers" (Ajzenshtadt, 1966: 87).

The tune "depicting" birds' singing reminds of the instrumental tune: it is light, agile, graceful in its own peculiar way. In the fairytale the bird sings, fluttering from one branch to another. Obviously, the tune aspires to illustrate this move, making the melody a little dancy.

It is evident that the "bird" language used to be a part of the "sound catalogue" of various Amur performers: the sound signs, onomatopoeitic in their way, were usually used to outline the ritual space of the shaman or to emphasize a special "vocal behaviour" of the story teller. In both cases the "voices" significated presence of these or those characters, making them visible.

There are some more generalized, stylized representations based on imitation of actions, where, besides audial perception, some kinetic elements were included. Thus, in the Udege legend of Dziugdeme the Unlucky and Khoio the Fish Girl, the soft and rocky rhythm inside the tertian motive is used to illustrate the move of the fish swimming in the river, with a single slight stroke:

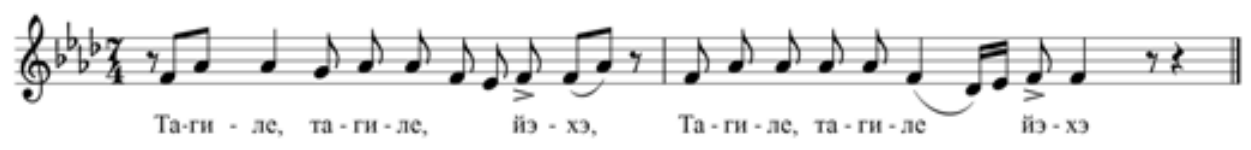

In this example the length of the vowels and consonants (ta-gi-le-e) is directly connected with the tempo and rhythm of the sound action, its duration and, especially, with the timbre characteristic of the phenomenon (sliding in the water, splashes). The bright visual image is borne by the combination of the audial and kinetic elements.

Another kinetic imitation is found in the Nanai fairy-tale Bia pikteni ("The Moon's other:

Daughter"). The words the main character, a beautiful girl named Biralda, says to Mergen, a man living on the Sun, are sung to the motive with the diapason of a sixth. The element that brings the tune to match the words of Mergen is the rhythm in the even numbered bars, used to illustrate the smooth movement of skiing, during which the characters talk to each 


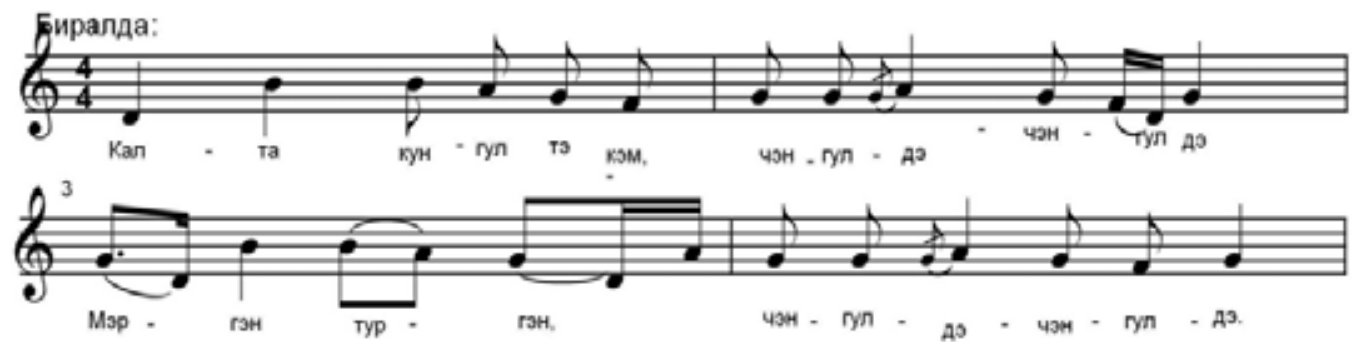

Thanks to the wide use of descriptive techniques in the characters' utterances (along with the use of gestures and mimics as means of expression), the Amur fairy-tale became spectacular; it did not just narrate, it also described, illustrated, represented. To represent images (of people, animals, or birds) in artistic way the performer could gesture actively, remaining static, and turn to spatial and audial kinematic techniques. The performer was a sort of a "one actor's theatre", playing two or more roles at the same time, each of which would have its own audial and kinetic characteristics. When the intoned became visible, the contact with the audience was built, and a listener turned into a viewer.

Just like in a ritual, in a fairy-tale the "friendly" was represented as human world: the world which is here and now, where the listener, the performer and the fairy-tale are. Intonationally, it refers to the calm narrative speech of the story teller. The "foe" is the world of the narration itself, the world of the images that break into the present through the direct first person speech of the characters (Nanai: addressed songs diari ningmani). Its intonation sphere consists of recitative and declaiming or chanting and declaiming vocal fragments. In this case singing was used in its signification function, as a means of isolation from everyday colloquial speech with the specific, rhythmically organized pronunciation of a word in a certain pitch, by means of melodization of the utterance. It served as a sort of sound mask, concealing the performer and marking the character's voice in the words he says. It may be the idea of the "voice" as a representative of this or that person that created the idea of the affinity of fairy-tale and ritual, as both are used to make contacts with a different, non-human world: reality of sound makes characters "present" here (Novik, 2000: 73).

Generally speaking, stylized sound imitations are more compound in comparison with iconic ones. Iu.I. Sheykin remarks that the onomatopoeia "acculturized in folklore practice acoustically incorporates some changes in both pitch and rhythm», they "fluctuate from iconic accuracy to unrecognizable modification depending on the cultural meaning assigned to such imitations (Sheykin, 1988: 16). Later stylized imitations were inevitably developed in artistic way, forming musical figurativeness as such, where nature intertwined with human spiritual life, or "nature was animated through intonations" (B.V. Asafyev), i.e. musical fragments were extracted from the ceremonial performance syncretism. Examples of such compositions left outside the ritual performance but still played to entertain the audience were found by E.A. Kreynovich back in 1927. He mentioned a series of expressive tunes played on t'ynryn, or a unichord violin: "Singing and Playing of Two Swans", "The Cuckoo", "Duck's Voice", "Bark of a Small Buggy Puppy Who Begs For Some Jellied Meat". Some of them were pretty extensive compositions with a particular story: for example: "One Nivkh comes to another Nivkh, and they hear the roar of a bear which came to the village and dogs' barking. The Nivkh shouts, asking for his spear" (Kreynovich, 1937: 80). 
The symbolic imitation logic creates instrumental compositions with a particular plot and a theme. Those are compositions that are not performed just as they are, they are "about someone" or "about something". The presence of such composition means that in the early folk music there were some developed ethno-aesthetic priorities, concepts of beautiful and unbeautiful sounds. The beauty is not in the melodic richness and lyricism, but in the finest shading, intonement able to reproduce and generalize the sounds of nature, to make the audial visible and vivid.

3. Non-verbal forms of speech intonement. The non-verbal form of speech intonement is onomatopoeia, i.e. various sound imitating combinations ("descriptive words") that reflect the similarity between the visible reality and its reflection in the language, typical for Tungus and the Far Eastern Nivkh. According to the definition presented by D. Rozental, "Onomatopoetic words are formations representing reflective exclamations of people, sounds made by animals and birds, sounds of natural phenomena, sounds made by objects etc."(Rozental', 1985: 81). For example, torororo (Nivkh) is the sound made by a hare, $k v h-k v h$ is the seagull voice, chuck-chuck (Nanai) is the sound made by a crow, ko-ko-kok (Nanai) is the voice of an eagle, chien-chien (Nanai) is the sparrow tweet (Avrorin, 1961: 213). Such interpretation seems to compare birds' singing and animals' voices to meaningful sounds of human speech. Among the features of descriptive words there is lesser abstraction and generalization, reflection of certain conceptual characteristics of objects and their actions. Such onomatopoeic words were sporadically used in ceremonial performances, such is in the Nivkh birds' calling ritual mentioned above.

In the intonement culture of the regional peoples there are some other sounds produced by representatives of the local fauna. In the ritual rhythm of Unnakai bear celebration the imitation of birds' wingbeat par-par is used (Mamcheva, 2003: 154). E. Kreynovich lists some other verbal onomatopoeia: patkh-patkh for a wounded bird's wingbeat, khiu-khiu for the sounds made by the wings of a flying bird, a descriptive word tyr meaning the sudden fall of a shot bird, tif imitating the sound of the shot bird falling on the ground and chaf for the splash of the shot bird against the water (Kreynovich, 2001: 106).

As a bear occupies a special place in the mythology and culture of the mythology and culture of the peoples of the South of the Russian Far East, it is natural that the sounds produced by this or that animal are frequently represented in verbal imitations. E.A. Kreynovich presents a big number of such "descriptive words": "The sounds produced by a bear are usually imitated by the Nivkh as follows: u"utrn"utr is a bear's roar; chalfchalf is the sound a bear makes as it walks in shallow water; tutuh ad is the sound a bear makes as it walks in deep water: t'ukh ad is the sound of a bear's jump into the water; tukhm is the sound produced when a bear catches a fish with its paws; $k$ " faf $k$ " faf is a descriptive word that imitates the quiet fall of a bear shot to death" (Kreynovich, 2001: 133).

The richness of the sound instruments of the Amur culture and the subtle acoustic details they convey are extremely impressive. The imitative approach formed in the ancient times under the influence of the peoples' life conditions determined the performance techniques of the ethnic ceremonial performances. The complex of these techniques formed the sound code of the traditional Amur culture. The ethnic rituals' acoustic component based on sound imitation is one of the ethnic constants which helps, along with the others, to preserve the "core component of the culture".

Summarizing everything said above, let us emphasize the following: 
1. The acoustic ethnic space of the peoples of the Amur-Sakhalin Region, intensively loaded with sounds of nature, made direct impact on the people living in such conditions. The origins of the Amur audial world outlook should be sought for in the complex of the visual, emotional and sensual, kinetic, timbre representations, associated with sound imitation in the Amur ceremonial performance. Imitation of the environment sounds is made through vocal and instrumental, accurate and stylized imitations of the sounds of physical and biological nature, as well as non-verbal forms of acoustic imitation: natural phenomena, vocal and mechanical signals of animals and birds, sounding human kinetics etc. This type of sound representation is a part of the most ancient type of communication between human and the surrounding world.

2. In the context of mythological thinking, perceiving and reflecting the world in the diversity and unity of its material and spiritual representations, where the sound (or "voice") is an essential attribute of the living, acoustic cognition of the space caused semiotization of natural sounds. They were given meanings and perceived as voices of certain subjects, communicative partners, real or mythological, not just like random noises.

3. Due to syncretic consciousness, the acoustic component of the Amur rituals did not just create sound impressions, but also translated them into visual, demonstrating the audio-visual unity of the tribal man's consciousness. It was a sort of visualization of the "voices" with certain recognizable images behind them. Such preconscious and systematic translation from one type of modality ("visual") to another ("audial") is typical for archaic cultures and is known as one of forms of synaesthesia (Zinchenko, 2011: 1). Due to the synesthetic experience the perception of the sounds recognized as "voices", not as "random sounds", people would see visual images, imagining the "bearers" of the voices. Such thinking with no gap between the visual and audial perception is generally typical of archaic cultures and matches their syncretic state, where the functions of thinking and perception are not separated from each other.

\section{References}

Avrorin, V. A. (1961) Grammatika nanayskogo iazyka [Nanai Language Grammar], Volume 2. Morfologiia glagol'nykh i narechnykh chastey rechi, mezhdometiy, sluzhebnykh slov $i$ chastits [Morphology of Verbal and Adverbal Parts of Speech, Conjunctions, Auxiliary Words and Particles]. Moscow-Leningrad, Izd-vo AN SSSR.

Ayzenshtadt, A.M., Narva, Kh.Ia., Portugalov, V.V. (1966) Muzykal'nyy fol'klor narodov Severa i Sibiri [Musical Folklore of the Peoples of the North and Siberia]. Moscow, Muzyka.

Zinchenko, A.A., Kartavenko, M.V. (2011) Sinesteziia - fenomenologiia, vidy, klas-sifikatsii [Synaesthesia: Phenomenology, Types, Classifications], In Informatika, vychislitel'naja tehnika $i$ inzhenernoe obrazovanie [Informatics, Computers, Engineering Education], 3 (5). p. 1-13.

Kolosovskiy, A.S. (2008) Nivhskie shamany (iz dnevnikov 1973-2007 gg.) [The Nivkh Shamans (From Diaries of 1973-2007)], In Izvestiia instituta naslediia Br. Pilsudskogo pri Sakhalinskom gosudarstvennom oblastnom kraevedcheskom muzee [Newsletter of the Heritage Institute Named After Br. Pilsudinsky of Sakhalin State Museum of Regional Studies], 12. Yuzhno-Sakhalinsk, Sakhalinskoe oblastnoe knizhnoe izdatel'stvo, p. 232-272.

Kreynovich, E.A. (1937) Fonetika nivhskogo (giliatskogo) iazyka [Phonetics of the Nivkh (Giliats) Language], In Izdanie nauchn.-issled. assotsiatsii In-ta narodov Severa. Trudy po lingvistike 
[Publication of the Scientific Research Association of the Institute of Northern Peoples. Linguistics], V. Moscow-Leningrad, $126 \mathrm{p}$.

Kreynovich, E.A. (2001) Nivkhgu [Nivkhgu]. Yuzhno-Sakhalinsk, Sakhalinskoe knizhnoe izd-vo, 520 p. Lacan, J. (1964) Chetyre osnovnye poniatiia psikhoanaliza (Seminary: Kniga HI) [The Four Fundamental Concepts of Psychoanalysis (Seminars: Book HI)], Moscow, Gnozis, Logos.

Lopatin, I.A. (1921) Nabliudeniia nad bytom gol'dov [Observing The Life of the Golds]. Vladivostok, Gosudarstvennyy Dal'nevostochnyy universitet, $46 \mathrm{p}$.

Lotman, Iu.M. (1994) Lektsii po struktural'noy poetike [Lectures on Structural Poetics], In Iu.M. Lotman i tartusko-moskovskaia semioticheskaia shkola [Iu.M. Lotman and the Tartu-Moscow Semiotic School], Moscow, p. 11-246.

Mamcheva, N.A. (1995) Variantnost' v fol'klore malochislennykh narodov Sakhalina [Variability in the Folklore of Small Indigenous Peoples of Sakhalin], In Vestnik Sakhalinskogo muzeia, 1.

Mamcheva, N.A. (2003) Obriadovye muzykal'nye instrumenty aborigenov Sakhalina [Ceremonial Music Instruments of the Sakhalin Aborigenes], Yuzhno-Sakhalinsk, Izd-vo SahGU, 176 p.

Mamcheva, N.A. (2006) Magicheskaia rol' zvukovoy kul'tury nivkhov [The Magic Role of the Nivkh Sound Culture], In Izvestiia instituta naslediia Br. Pilsudskogo pri Sakhalinskom gosudarstvennom oblastnom kraevedcheskom muzee [Newsletter of the Heritage Institute Named After Br. Pilsudinsky of Sakhalin State Museum of Regional Studies], 10, Yuzhno-Sakhalinsk: Sakhalinskoe oblastnoe knizhnoe izdatel'stvo, p. 138-163.

Mamcheva, N.A. (2008) Sakral'noe znachenie muzykal'nykh instrumentov nivkhov [Sacral Significance of the Nivkh Music Instruments], In Izvestiia Rossiyskogo gosudarstvennogo pedagogicheskogo universiteta im. A.I. Gertsena [Newsletter of Russian State Pedagogical University Named After A.I. Herzen], 86, p. 132-135.

Novik, E.S. (2000) Fenomen golosa v fol'klore i verovaniiakh narodov Sibiri [Voice Phenomenon in the Folklore and Beliefs of Siberian Peoples], In Evraziyskoe prostranstvo. Zvuk i slovo [Eurasian Space. Sound and Word], Moscow, p. 68-74.

Podmaskin, V. V. (1987) Muzykal'nye instrumenty udegeytsev [Udege Music Instruments], In Natsional'nye traditsii v kul'ture Dal'nego Vostoka [National Traditions in the Far East Cultures], Vladivostok.

Rozental, D.E., Telenkova, M.A. (1985) Slovar'-spravochnik lingvisticheskikhterminov [Linguistic Terms Dictionary], Moscow, Prosveshchenie.

Sem, Iu.A. (1988) Vospitanie detey v traditsionnoy kul'ture nanaycev [Child-Rearing in Nanai Traditional Culture], In Traditsionnoe vospitanie detey u narodov Sibiri [Traditional Child-Rearing of Siberian Peoples], Leningrad, Nauka, p. 121-139.

Slovar' muzykal'no-etnograficheskikh terminov [Musical and Ethnographic Terms Dictionary] (2000), In Muzykal'naia etnografiia tunguso-man'chzhurskikh narodov: tez. mezhdunar. konf. [Musical Ethnography of the Tungusic Peoples], Yakutsk, p. 93-108.

Smoliak, A.V. (1991) Shaman: lichnost', funktsii, mirovozzrenie (narody Nizhnego Amura) [Shaman: Personality, Functions, World Outlook (Lower Amur Peoples)]. Moscow, Nauka.

Sheykin, Iu.I. (2002) Istoriia muzykal'noy kul'tury narodov Sibiri: Sravnitel'no-istoricheskoe issledovanie [History of Musical Culture of Siberian Peoples: Comparative Historical Research], Moscow, Vostochnaia literatura RAN. 
Sheykin, Iu.I. (1988) Aktual'nye problemy muzykal'noy etnografii Severnoy Azii (vmesto predisloviia) [Current Problems of Musical Ethnography of North Asia (Instead of Introduction)], In Muzykal'naia etnografiia Severnoy Azii [Musical Ethnography of North Asia], 10. Novosibirsk.

\section{Слышать ergo, видеть, или Об акустической специфике обрядового зрелища амурских этносов}

\section{Я.С. Крыжановская}

Хабаровский государственный институт культуры Россия, 680045, Хабаровск, ул. Краснореченская, 112

Статья посвящена анализу акустической составляющей в традиционной культуре этносов юга Дальнего Востока. Признавая значимость «обрядово-зрелищного текста» как сложной системы хореографического, сиенографического и акустического начал, автор акцентирует зрелищную основу обрядового синкретизма. Показано, что истоки амурского звукового мировосприятия следует искать в комплексе зрительных, эмоционально-чувственных, кинетических проявлений, связанных с имитационной сферой в амурских обрядовых зрелищах. Развивается мысль о том, что благодаря синкретическому сознанию акустический ряд амурских обрядов давал не только звуковые впечатления, но и переводил их в зрительные, демонстрируя аудиовизуальное единство сознания племенного человека.

Ключевые слова: этнос, обрядовое зрелище, амуро-сахалинский регион, синкретизм, звуковая имитация.

Научная специальность: 24.00.00 - культурология. 